Medicine and Surgery.-Montyon prizes to Félix Lagrange (2500 francs), L. Ombredanne and R. Ledoux-Lebard (2500 francs), A. Mignon, Henry Billet, and Henri Martin (2500 francs); mentions to André and Joseph Chalier ( 1500 francs), Alfred Khoury (1500 francs), and E. Velter (I500 francs); a citation to Henri Velu; the Barbier prize to L. Bruntz and Marcel Jaloux, for their memoir on medicinal plants; the Bréant prize (arrears of interest) between Jean Pignot (2000 francs), Maurice Loper (I500 francs), and Julien Dumas (1000 francs). The Bellion prize is not awarded, but encouragements (500 francs each) are accorded to Josefa Ioteyko, for her researches on fatigue and muscular work; to $R$. Legendre, for his contributions to the treatment of carbon monoxide poisoning, artificial respiration, and studies on bread manufacture; and to B. Roussy, for his book on the domestic education of women. The Baron Larrey prize is not awarded, but A. Rochaix receives a recompense (500 francs) for his studies on the rapid detection of sewage contamination in drinking-water. No awards were made of the Mège and Godard prizes.

Physiology.-The Montyon prize to Stéphen Chauvet, for his memoir on infantilism; the Lallemand prize to Henry Cardot and Henri Laugier, for their work on the electrical stimulation of nerves; the L. La Caze prize to Raphaël Dubois, for the whole of his work in physiology; the Pourat prize, no memoir on the subject proposed has been received; the Martin-Damourette prize to Gérard de Parrel, for his work entitled "Précis d'anacousie vocale et de labiologie"; the Philipeaux prize to Hugues Clément, for his studies on the application of the centrifuge in producing alterations in the development of the egg and embryo in several animals; the Fanny Emden prize is not awarded, but the arrears are attributed to Mme. Albert Dastre.

Statistics.-The Montyon prize is not awarded.

History and Philosophy of the Sciences.-The Binoux prize to Maurice Delacre, for his memoir on the history of chemistry.

Medals.-Berthelot medals are awarded to André Labat and to Marcel Guichard.

General Prizes.-The Bordin prize, no memoirs received dealing with the subject proposed; the Estrade Delcros, Le Conte, Parkin, and Wilde prizes are not awarded; the Houllevigue prize to the late Camille Tissot, for the whole of his work; the Saintour prize to René Kœhler, for his work in zoology; the Henri de Parville prize between R. Devillers (I50o francs), for his book on the dynamics of the aeroplane, and Hector Pécheux (rooo francs), for his book on metallurgy; the Lonchampt prize to Emile Guyenot, for his studies on the growth of organisms under aseptic conditions; the Caméré prize to Paul Séjourné, for his engineering work; the Victor Raulin prize to Jules Rouch, for his work in meteorology, atmospheric electricity, and physical oceanography; the Gustave Roux prize to the late Georges Boyer, for his geological work; the Thorlet prize to Adolphe Richard.

Special Foundations.-The Lannelongue foundation to Mmes. Cusco and Ruck; the Laplace prize to Jean Vignal; the L. E. Rivot prize to Jean Vignal (750 francs), Paul Reufflet (500 francs), Henri Scaillierez ( $75^{\circ}$ francs), and Camille André Antoine (500 francs).

Foundations for Scientific Research.-The Trémont foundation (rooo francs) to Charles Frémont, for his researches relating to the working of metals; the Gegner foundation between F. Pisani (2000 francs), for his work in mineralogical chemistry, and the late Samuel Lattè, for his work on mathematical analysis; the
Jérôme Ponti foundation between Paul Barbarin (2000 francs), for his work on non-Euclidean geometry, and Louis Fabry (I 500 francs), for his work on the smaller planets; the Henri Becquerel foundation between Camille Gutton (2000 francs), for his work in physics, especially that having reference to the national defence; Pierre Fatou, 2000 francs.

The Bonaparte Foundation.-Twenty-one requests for grants have been considered, and the following six are recommended :-200o francs to E. de Boury, to allow him to continue his studies of the gasteropod molluscs; 3000 francs to Auguste Chevalier, for his studies on the forest flora of Indo-China, and for his researches on the woods of that region capable of being utilised; 2000 francs to Paul Garrigou-Lagrange, for the continuation of his meteorological studies and attempts at the kinematography of the atmospheric movements; 2000 francs to Louis Germain, for the publication of his works on the malacological fauna of Africa and Asia, and for the continuation of his study of the molluscs of the Loire basin and the French coast of the Atlantic Ocean; 2500 francs to C. Le Morvain for completing the publication of the "Carte photographique et systématique de la lune"; 5000 francs to $\mathrm{H}$. Perrier de la Bathie, for the continuation of the geological and botanical researches which he has pursued with success at Madagascar for many years. The balance of the fund in hand, after payin the above grants, amounts to 72,500 francs.

The Loutreuil Foundation.-400o francs to R. Anthony, for printing the osteological catalogue of the collections of the National Museum of Natural History; 5000 francs to Charles Moureu, for completing the equipment and collections of the laboratory of the College de France; 5500 francs to the Lyons National Veterinary School, for the installation of a kinematograph for teaching purposes; 3000 francs to the Toulouse National Veterinary School, to complete the radiological installation for the diagnosis of diseases of animals; 4000 francs to Edouard Sauvage, for the construction of an apparatus designed to study the forces of inertia in the parts of a machine; rooo francs to E. Ariès, for the purchase of a calculating machine for use in his researches on the equation of state of fluids; 2000 francs to Henry Bourget, for assisting the publication of the Journal des Observa teurs; 2000 francs to Maurice Cossmann, for his various publications on palæontology; 2000 francs to A. Ménégaux, for the French ornithological review; 6000 francs to Aloys Verschaffel, for the calculation and publication of the ephemerides of the minor planets, according to a plan approved by the Bureau des Longitudes: 5000 francs to Col. Roche, for the equipment of the laboratory of the Ecole Supérieure d'Aéronautique.

Charles Bouchard Foundation.-200o francs to Jean Nageotte and Louis Sencert, for researches on grafting with dead tissues; 1500 francs to Paul Brodin and François Saint-Girons, for their work on bleeding; I 500 francs to Pierre Duval and Adrien Grigaut, for their researches on traumatic shock.

\section{A NEW THEORY OF THE ICE AGE.}

TWO recent papers in the Quarterly Journal of the

Royal Meteorological Society by Mr. C. E. P. Brooks have emphasised the point of view that there is no necessity to appeal to astronomy or to make any arbitrary assumptions, such as that of a specially cold region in space, in order to account for an Ice age. The subject of the papers is "Continentality and Temperature" (Quart. Journ. Roy. Met. Soc., vol. xliii., pp. I59-73, and vol. xliv., pp. 253-70), and NO. 2565 , VOL. IO2] 
the author's endeavour is to correlate mean temperature at certain stations with the distribution of land and water in the neighbourhood of the stations, first for a definite region, including the Baltic and most of northern Europe, without much range of latitude, and next tor the world in general, with special reference to latitude.

It is clear that very definite results are unlikely, having regard to the very irregular distribution of land and its topographical peculiarities; and not less clear that a great deal of labour must have been involved in obtaining any result whatever. The temperature of a place is affected by the size, distance, and dircction of land and water masses in relation to the prevailing winds, and also by the relief of the land and the temperature of the neighbouring sea. The correction for height above sea-level is apparently straightforward and simple, but in regard to the others it was only convenient to take as a first approximation the percentage of land included in circles of $5^{\circ}, 10^{\circ}$, and $20^{\circ}$ radius, centred at the station in question, and the resulting correlations are by no means easy of interpretation.

Certain stations introduce special difficulties, e.g. Haparanda, where the continentality is not the same throughout the year owing to the freezing of the sea in winter. There are, however, some general conclusions worth quoting:-( $\mathrm{r}$ ) In winter the effect of land to the west is to lower temperature. (2) In winter the effect of land to the cast is almost negligible, so that even in continental areas the lowest temperatures are found near the eastern coasts. (3) The general effect of land in the summer either east or west is to raise temperature, but not to anything like the same extent as the opposite effect in winter.

Special interest attaches to the extension of the investigation with regard to long intervals of time. In the Litorina (early Neolithic) period the climate of the Baltic regions was rather different, as also were the distribution of land and the freedom of access from the Atlantic. In the first paper, which deals specially with this region, the author claims that the alterations of continentality suffice to account for all the historic variations of local temperature. A more important generalisation follows in the second paper, in which the author considers the period immediately preceding the last or Quaternary glacial period. An outline is given of the distribution of land at that period, and an explanation of the formation of ice-sheets by reason of fall of temperature and increase of snowfall, the argument being almost entirely meteorological. The next step, however, is of a different kind, and the theory of isostasy is summoned to account for the gradual upsetting of an apparently permanent claciation. The weight of the masses of ice causes the subsidence by slow degrees of the ground below equilibrium being gradually restored by the fiuid interior. The sinking of the ice-surface causes an increase of temperature with consequent melting. The isostatic action is, however, so slow that the surface continues to sink, causing a higher temperature in higher latitudes (inter-glacial period). After a time the equilibrium, which is clearly disturbed in the opposite direction, induces isostatic action again, raising the land-surface and causing another glaciation. "The author considers that this "ebb and flow" has taken place four times in succession, the amplitude diminishing rach time, as is to be expected.

The course of these age-long changes is not quite so simple as its general outline, for manv irregularities are necessarily introduced by the disposal of the melting ice, which will depend on the geographical features thi!s uncovered, and, again, by the locking up of so much moisture into glaciers; but the explanation of such well-known phenomena as the warm period of the Tertiary by this geographical method appears more straightforward than any depending on assumptions as to the effect of changes in the obliquity of the ecliptic-an effect which we are almost powerless to forecast.

The purely metcorological part of the subject is not without difficulties of its own, some very anomalous figures for sea temperature in high latitudes resulting from the attempt to deal with the earth as a whole, and to allow for the vagaries of land distribution and of ocean currents. The effect of insolation in different latitudes and on different land and water surfaces is a very difficult problem, and so also is the question of precipitation, but $\mathrm{Mr}$. Brooks is not afraid to tackle these difficulties, and must have brought an enormous amount of research to bear, in addition to the very laborious and complicated analysis of the data obtained. It is to be hoped that this subject will not escape the notice of the British Association Geophysical Committee.

W. W. B.

\section{REPORT OF THE DEVELOPMENT COMMISSIONERS.}

$T \mathrm{HE}$ report of the Development Commissioners for the year ended March 31, 1918, has been published as a Parliamentary Paper (i 8 , price $3 d$. net), extracts from which are subjoined. Except so far as the special circumstances of the war have called for extended expenditure or new schemes in respect of food supply and natural products, or for the preliminary outlay in the preparation of schemes which may employ labour after the war, the Commissioners have continued the policy which they have adopted since the commencement of the war of confining their advances in the main to ensure the continuity of schemes which were already in working in I9I4, and cannot properly be discontinued. In one instance, that of flax-growing, the expansion owing to war needs has led to an increase of the undertaking to a scale on which it is no longer of an experimental or educational nature, such as is appropriate for assistance from the Development Fund, and the undertaking has accordingly been taken over by the Board of Agriculture.

In the introduction to last year's report mention was made of an advance of 50,oool. for improving the fish food supply by installing motors in fishing-boats. But the problems of this supply are not solved by the mere catching of fish; there remain the problems of its rapid delivery or preservation. In connection with these latter points the Commissioners have recommended an advance of $675 \mathrm{ol}$. in aid of landing and entraining facilities at Valentia, and in January, ז9 18 , they promised to recommend an advance (later fixed at io,oool.) for the establishment of an experimental fish-canning factory on scientific lines.

Reference was also made last year to the extra expenditure on a largely increased supply of plants for afforestation, and this has continued in the year now under review. Thus an advance of $6905 l$. to the Commissioners of Woods for this purpose has been recommended; while in Scotland, in addition to ordinary expenditure, grants of $2000 l$. for each of the financial years, I9I7-I8 and I9I8-19, were recommended to meet expenditure on the establishment of forest nurseries, and $930 l$. for an additional Forest Officer on the staff of the Board of Agriculture. A sum of roool. was also made available for preliminary arrangements for the afforestation of privately owned lands and a flying survey.

$$
\text { NO. } 2565 \text {, VOL. IO2] }
$$

